\title{
OECD Ülkelerinin Lojistik Performanslarının SWARA Tabanlı EDAS Yöntemi ile Değerlendirilmesi
}

\author{
Ayșe Cansu GÖK KISA \\ Hitit Üniversitesi, IIIBF, Uluslararası Ticaret ve Lojistik Bölümü, \\ cansugok@hitit.edu.tr,ORCID:0000-0001-7594-4856 \\ Ejder AYÇİN \\ Sorumlu Yazar, Munzur Üniversitesi, İ̈BF, Isşletme Bölümü, \\ eaycin@munzur.edu.tr ORCID: 0000-0002-0153-8430
}

\begin{abstract}
$\ddot{O ̈ z}$
Son yıllarda, hem ülkelerin ulusal ekonomilerinde olușturduğu etki hem de rekabet gücüne katkısı sebebiyle lojistik sektörüne verilen önem artmıştır. Lojistik performansı yüksek olan ülkelerin ticari faaliyetlerinin de gelişmiş olduğu görülmektedir. Bu çalışmada çok kriterli karar verme yöntemleri bütünleşik olarak kullanılarak, OECD ülkelerinin lojistik performanslarının değerlendirilmesi amaçlanmıştır. Ülkelere ilişkin veriler Dünya Bankası tarafından yayımlanan raporlarda yer alan lojistik performans göstergelerinden elde edilmiştir. Çalışma kapsamında yer alan lojistik performans kriterlerinin önem ağıllıkları SWARA yöntemi ile hesaplanmış, ülkelerin lojistik performansları ise EDAS yöntemiyle analiz edilmiştir. Uygulama sonuçlarına göre, en önemli kriterler lojistik hizmet kalitesi, altyapı ve uluslararası sevkiyat olarak belirlenmiștir. Lojistik performansı en yüksek olan ülkelerin ise sırasıyla Almanya, Hollanda ve İsveç olduğu sonucuna ulaşılmıştır.
\end{abstract}

Anahtar Kelimeler: Lojistik Performansı, Çok Kriterli Karar Verme, SWARA, EDAS. JEL Sınıflandırma Kodları: C44, O57

\section{Evaluation of the Logistics Performance of OECD Countries with EDAS Method Based on} SWARA ${ }^{1}$

\section{Abstract}

In recent years, the importance given to the logistics sector has increased due to both its impact on national economies and its contribution to competitiveness. It is observed that commercial activities of countries with high logistics performance have also improved. In this study, it is aimed to evaluate the logistics performance of OECD countries in an integrated way by using multi criteria decision making methods. Country data are obtained from the logistics performance indicators included in the reports issued by the World Bank. The importance of the logistics performance criteria within the scope of the study was calculated by SWARA method and the logistics performance of the countries was analyzed by EDAS method. According to the results of the application, the most important criteria are determined as logistics service quality, infrastructure and international shipment. It is concluded that the countries with the highest logistics performance are Germany, the Netherlands and Sweden, respectively.

Keywords: Logistics Performance, Multi Criteria Decision Making, SWARA, EDAS.

JEL Classification Codes: C44, O57

${ }^{1}$ Extended abstract is presented at the end of the article.

Geliş Tarihi (Received): 21.12.2018 - Kabul Tarihi (Accepted): 29.03.2019

Atıfta bulunmak için/Cite this paper:

Gök Kısa, C. ve Ayçin, E. (2019). OECD ülkelerinin lojistik performanslarının SWARA tabanlı EDAS yöntemi ile değerlendirilmesi. Çankırı Karatekin Üniversitesi İ̈BF Dergisi. 9 (1), 301-325. 


\section{Giriş}

Ekonominin küreselleşmesiyle birlikte ürün ve pazar çeşitliliğinin artarak ticaretin uluslararası boyutlara taşınması lojistik sektörüne verilen önemi giderek arttırmıştır. Lojistik, üretim noktasından tüketim noktasına kadar her türlü malzeme ve bilgi akışının etkin şekilde düzenlenmesine ilişkin faaliyetleri kapsaması bakımından ekonomi ile doğrudan bağlantılıdır. Bu nedenle, lojistik faaliyetler ülkelerin veya bölgelerin ekonomik üstünlük ve rekabet gücü elde edebilmesi için önemli bir araç haline gelmiştir.

Lojistik hizmetlerin etkin olması ülkeler arasındaki ticaret ağının genişlemesi, yabancı sermaye yatırımlarının artması ve ekonominin büyümesi açısından büyük paya sahiptir (Arvis vd., 2010, s. 1). Ticareti zorlaştıran etkin olmayan bir lojistik yapı, zaman ve maliyet olarak kayıplara sebep olmaktadır. Kaliteli lojistik hizmetlerin varlığı, taşıma sırasında oluşan maliyetleri düşürerek ülkenin rekabet edebilirliğini yükseltmektedir (Korinek ve Sourdin, 2011, s. 5). Maliyetlerin artması özellikle küresel pazarlarda rekabet etmeye çalışan gelişmekte olan ülkeleri daha fazla olumsuz etkilemektedir (Arvis vd., 2018, s. 1).

Hizmet sektörünün büyük bir parçası olan lojistik sektörünün ulusal ekonomide oluşturduğu etki, ülkelerin gelişmişlik düzeylerinin belirlenmesinde önemli bir unsurdur. Lojistik maliyetlerin yüksek olması ülkelerin ekonomik büyümelerini yavaşlatmaktadır (Deniz Ticaret Odası, 2017, s. 10). Ülkemizde 2000'li yıllardan itibaren büyüme hızını arttıran lojistik sektörü, taşımacılığın yanı sıra depolama, gümrükleme, sigortalama, paketleme ve katma değerli hizmetler, sipariş ve stok yönetimi, muayene faaliyetlerinin eşgüdümlü yapılmasını gerektirmektedir. Son yıllarda sektörde karma taşımacılık (multimodal, intermodal ve kombine) kapsamında çözümler sunulmuş, çağdaş depo yatırımları gerçekleştirilmiş, hizmet çeşitliliği ve kalitesi artmıştır (MÜSİAD, Tanyaş, 2015, s. 21).

Lojistik, hem kendi içinde taşıdığı büyüme potansiyeli hem de Türkiye'nin birçok ekonomik hedefe ulaşmasında oynayacağı rol itibarıyla oldukça önem taşımaktadır. Lojistik hizmetlerin dünya genelindeki hacmi gün geçtikçe artarken, lojistik altyapısı gelişmiş ülkelerin ticaret faaliyetlerinin daha etkili ve verimli olduğu görülmektedir (Kalkınma Bakanlığı, 2013, s. 122). Dünyada lojistik pazarın büyüklüğü yaklaşık 5 trilyon dolar civarında olup, yeryüzünde üretilen her 1 dolarlık değerin en az \%25'i lojistik kapsamındaki faaliyetlerden elde edilmektedir. AB lojistik pazarının büyüklüğünün ise yaklaşık 627 milyar Euro değerinde olduğu ifade edilmektedir. Türkiye'nin ise 2016 yılında 720 milyar dolar olarak gerçekleşen Gayri Safi Yurtiçi Hasıla (GSYIH) içindeki lojistik sektörü payının 100 milyar doların üzerinde olduğu, GSYİH'nın \%14'ünün lojistik hizmetlerden oluştuğu bilinmektedir (Deniz Ticaret Odası, 2017, s. 10). 
Dünya Bankası'nın 2007 yılından itibaren düzenli olarak ülkelerin lojistik performansını ölçmek için yaptığı kapsamlı araştırmada sunduğu Lojistik Performans İndeksi (LPI) temel alındığında, Türkiye'nin lojistik performansının son yillarda pek ilerleme kaydetmediği görülmektedir. 2007 yılında 3,15 puanla 34., 2010 y1lında 3,22 puanla 39., 2012 yılında 3,51 puanla 27., 2014 y1lında 3,50 puanla 30., 2016 y1lında 3,42 puan ile 34. sira yer almaktadır. 2018 y1lı raporunda ise Türkiye bir miktar gerileme göstererek 160 ülke arasında 3,15 puanla 47. sırada bulunmaktadır. LPI sıralaması, Dünya Bankası tarafından lojistik firmalarıyla yapılan kapsamlı bir anket yoluyla ülkelerin lojistik performanslarının 6 ana göstergeye göre değerlendirilmesi sonucunda elde edilmektedir. Yaklaşık 6000 adet ülke değerlendirmesi dikkate alınmaktadır. Yayımlanan bu indeks lojistik performansı çalışmalarına da konu olmaktadır.

Türkiye bulunduğu coğrafi konum ve ekonomik büyüme hedefleri doğrultusunda kalkınma planlarında da yer alan lojistik performansını iyileştirmeye yönelik hedeflerini yerine getirmek durumundadır. Ulusal ve uluslararası düzeyde sektördeki yerini ve gücünü iyi analiz etmelidir. Bu noktada ülkemiz kalkınma, ekonomi ve ticaret gibi konularda işbirlikleri içerisinde bulunmaktadır. Türkiye'nin de üyesi olduğu OECD (Ekonomik İşbirliği ve Gelişme Teşkilatı) ülkeleri içersinde en yüksek GSYİH büyümesine sahip olan ülkelerden biri Türkiye'dir. 2018 y1lı itibariyle y1llı \%5.1 büyüme oranına sahip olması ve 2018 ile 2030 yılları arasında ise $\% 4.3$ büyüme oranıla mevcut pozisyonunu sürdürmesi beklenmektedir (Ojala ve Çelebi, 2015, s. 9). Kuşkusuz Türkiye'nin bu pozisyonunu koruması ve yükseltmesi lojistik sektöründeki performansına da bağlı olacaktır.

Bu kapsamda, çalışmanın amacı OECD ülkelerinin lojistik performansının LPI göstergelerinin kullanılarak değerlendirilmesini sağlamak ve bu amaçla Çok Kriterli Karar Verme (ÇKKV) yöntemlerinden faydalanmaktır. ÇKKV teknikleri fazla sayıda kriter ve alternatifin bir arada değerlendirilmesini gerektiren problemlerin çözümüne imkan tanımaktadır. Çalışmada LPI altında yer alan 6 ana göstergenin kriter bazında ağırlıklandırma işlemini gerçekleştirmek için SWARA yöntemi kullanılmış ve uzman görüşlerinden yararlanılmıştır. OECD ülkelerinin lojistik performanslarına göre sıralanmasında ise EDAS yöntemi kullanılmıştır. Ayrıca çalışmanın kullanılan yöntemler ve lojistik performans değerlendirmesi açısından literatüre katkı sağlaması hedeflenmiştir.

Çalışmanın giriş bölümünü takiben ikinci bölümünde lojistik performans konusunda yapılan literatür taramasına yer verilmiştir. Üçüncü bölümde araştırmada kullanılan SWARA yöntemi ve dördüncü bölümde EDAS yöntemi açıklanarak beşinci bölümde OECD ülkeleri için yapılan uygulama sunulmuştur. Son olarak altıncı bölümde ise sonuç ve öneriler aktarılmıştır. 


\section{Literatür Taraması}

Lojistik performans konusunda yapılan çalışmalar incelendiğinde çeşitli göstergeler ve indeksler aracilığıyla ülkeler veya bölgeler bazında değerlendirmeler yapıldığı görülmektedir.

Dünya Bankası tarafından ülkelerin lojistik performansının belirlenmesine yönelik ilk olarak 2007'de yapılan kapsamlı bir çalışmayla Lojistik Performans Indeksi (LPI) raporu yayımlanmıştır. Daha sonraki araştırmalarda indeks geliştirilerek 2010 yılından itibaren iki yılda bir yayımlanan bir rapor haline gelmiştir. Diğer yandan Agility şirketinin 2011 yılından itibaren her yıl düzenli olarak yayımladğı araştırmada gelişmekte olan ülkelerin lojistik performanslarının değerlendirilmesine yönelik bir indeks ortaya koyulmuştur. Indekste pazar büyüklügü̈büyüme çekiciliği, pazar uyumluluğu ve pazarla bağlantılı olma (altyapı bakımından) gibi üç temel unsur dikate alınmıştır.

Shang ve Marlow (2005), Tayvan'daki üretim firmalarının lojistik kapasitesini ve performansını ölçmek amacıyla yapısal eşitlik modelinden yararlanarak lojistik kapasitesi, lojistik performansı ve finansal performans arasındaki ilişkiyi değerlendirmişlerdir. Kunadhamraks ve Hanaoka (2008), çalışmalarında Tayland'da modlar arası taşımacılığın lojistik performansını değerlendirmek üzere mod seçimi problemi için Bulanık Analitik Hiyerarşi Sürecini (BAHS) kullanmışlardır. Bayraktutan vd. (2012) Kocaeli'deki lojistik sektörünün durumunu ve potansiyelini araştırmak amaciyla yoğunlaşma analizi gerçekleştirmişler bunun yanında geliştirdikleri lojistik gelişmişlik indeksi ile Türkiye'deki iller için sıralama yapmışlardır. Güner ve Coşkun (2012), ekonomik ve sosyal faktörlerin ülkelerin lojistik performansına etkisini değerlendirmek için 26 OECD ülkesi üzerinde çalışma yapmışlardır. LPI verilerini kullanarak lojistik performans ile bazı ekonomik ve sosyal göstergeler arasındaki ilişkiyi korelasyon analizi ile incelemişlerdir. Çakır ve Perçin (2013), Fortune Türkiye dergisinin açıkladığı ilk 500 firma arasında yer alan 10 lojistik firmasının finansal kriterlere göre performansının ölçülmesi için CRITIC, SAW (Simple Additive Weighting), TOPSIS ve VIKOR yöntemini kullanmışlardır. Elde edilen sıralamaları bütünleştirmek amacıyla da Borda Sayım yönteminden faydalanmışlardır. Marti vd. (2014), LPI'nin uluslararası ticaretteki önemini saptamak için ağırlık merkezi yaklaşımını kullanmış ve gelişmekte olan ülkeler için indeksteki herhangi bir iyileşmenin ticarette de büyümeyi sağlayacağını öngörmüşlerdir.

Civelek vd. (2015), LPI'nin Küresel Rekabet İndeksi ve GSYİH ilişkisi üzerindeki aracı etkisini göstermek amacıyla 2007-2014 yılları için hiyerarşik regresyon analizini kullanmışlardır. Buna göre LPI'nın etkisi istatistiksel olarak anlamlı bulunmuştur. Gergin ve Baki (2015), Türkiye'deki bölgelerin lojistik performansını değerlendirmek için LPI göstergelerinin bölgelere uyarlanması ile belirlenen kriterlere göre AHS ve TOPSIS yöntemlerini kullanmışlardır. Elde edilen sıralamada Marmara Bölgesi birinci sırada yer almıştır. Ojala ve Çelebi 
(2015), OECD adına yaptıkları araştırmada lojistik performansın bileşenlerini değerlendirmek amaciyla LPI konseptini incelemiş ve Türkiye'nin mevcut ticaret ve ulaştırma yapısı, rekabet durumu doğrultusunda lojistik potansiyeline ilişkin değerlendirmelerde bulunmuşlardır.

Ayaydın vd. (2017), çalışmalarında Fortune Türkiye dergisinin açıkladığı ilk 500 firma arasına giren 10 lojistik firmasının finansal veriler ile performansının ölçülmesinde Gri İş̧kisel Analiz Yöntemini kullanmışlardır. Başar ve Bozma (2017), 2007-2014 döneminde 71 ülke için havuzlanmış panel veri analizi kullanarak LPI'nin makroekonomik ve politik belirleyicilerini ortaya koyan bir çalışma yapmışlardır. Yapraklı ve Ünalan (2017), Türkiye'nin son on yıldaki lojistik performansını analiz etmek amacıyla LPI ve indeksin bileşenlerine ait verileri yorumlamışlardır.

Yapılan literatür araştırması, lojistik performansının ÇKKV yöntemleri ile değerlendirildiği sınırlı sayıda çalışma olduğunu göstermektedir. Ayrıca Dünya Bankası'nın LPI verilerinden sıklıkla faydalanıldı̆̆ı göze çarpmakta ancak OECD ülkelerine ilişkin yapılan bir sıralama bulunmamaktadır. Bu çalışmada bütünleşik olarak ele alınan SWARA ve EDAS yöntemlerinin, lojistik performansının değerlendirilmesi amacıyla herhangi bir çalışmada uygulanmamış olması bakımından, mevcut çalışmanın literatüre katkı sağlaması amaçlanmaktadır.

Çalışma kapsamında yer alan SWARA ve EDAS yöntemlerinin literatürde farklı uygulama alanları bulduğu görülmektedir. Aghdaie vd. (2013) makine seçim sürecinde, Zolfani vd. (2015) Ar-Ge projesi seçim sürecinde, Karabasevic vd. (2015) personel seçiminde, Işık ve Adalı (2016) otel seçim probleminde, Shukla vd. (2016) kurumsal kaynak planlama seçim sürecinde, Çakır (2017) müteahhit firmanın seçiminde, Çakır ve Karabıyık (2017) bulut depolama hizmet sağlayıcılarının seçim sürecinde, Yurdoğlu ve Kundakçı (2017) sunucu seçim sürecinde, Adalı ve Işık (2017) tedarikçi seçim probleminde, Ayyıldız ve Demirci (2018) şehirlerin yaşam kalitelerinin belirlenmesinde, Karabıyık ve Gündoğmuş (2018) üniversitelerde bilgi sistemi seçim kriterlerinin belirlenmesinde, Çakır vd. (2018) Türkiye'deki özel alışveriş sitelerinin değerlendirilmesinde, Toklu vd. (2018) demir-çelik endüstrisinde tedarikçi seçim sürecinde, Özbek (2018) faktöring şirketlerinin mali yapılarının değerlendirilmesinde, Özbek ve Demirkol (2018) lojistik firmalarının performanslarının değerlendirilmesinde, Çakır (2018) elektronik belge yönetim sistemi yazılım seçim sürecinde SWARA yöntemini değerlendirme kriterlerinin ağırlıklarının hesaplanmasında kullanmışlardır.

Ghorabaee vd. (2016) tedarikçi seçim sürecinde, Ulutaş (2018) tekstil atölyesi için makine seçiminde, Özbek ve Engür (2018) lojistik firma web sitelerinin değerlendirilmesinde, Çakır (2018) en iyi elektronik belge yönetim sistemi yazılımının belirlenmesinde, Albayrak ve Erkayman (2018) sporcular için akıllı bileklik alternatifleri arasından seçim sürecinde EDAS yöntemini kullanmışlardır. 


\section{SWARA}

SWARA (Step-wise Weight Assessment Ratio Analysis), Keršuliene vd. tarafından 2010 yılında literatüre kazandırılarak birçok alanda uygulanan ve uzman görüşüne dayalı değerlendirmelere dayanan bir ÇKKV yöntemidir (Keršuliene vd., 2010).

$\mathrm{Bu}$ yöntemde uzmanlar kendi bilgi ve birikimlerinden yararlanarak her bir kriterin önemini kendine göre belirledikten sonra, ilk kriterden sonuncuya kadar tüm kriterleri sıralar. Sıralama süreci, en önemli kriter birinci sırada ve en az önemli kriter sonuncu sırada yer alacak şekilde tamamlanır (Keršuliene ve Turksis, 2011: 654). Kriter ağırlıklarının belirlenmesi sürecinde, kriterlerin önem oranı hakkındaki uzman görüşlerinin tahmin gücü bu yöntemin ana unsurudur (Agdaie vd., 2013: 8). Çok sayıda kriteri içerisinde bulunduran karar problemlerinin çözümünde, SWARA yöntemi ile çözüm yapılırken, diğer yöntemlere göre daha az sayıda ikili karşılaştırma yapılmaktadır. Karar probleminde yer alan $n$ adet kriter için $n$ - 1 adet karşılaştırma yeterli olacaktır (Stanujkic vd., 2015, s. 182).

SWARA yöntemi altı aşamadan oluşan bir uygulama sürecine sahiptir (Keršuliene vd., 2010; Ruzgys vd., 2014; Stanujkic vd., 2015; Karabasevic vd., 2016).

1. Aşama: Kriterlerin ve Karar Vericilerin Belirlenmesi: İlk aşamada karar probleminde yer alacak kriterler ve karar vericilerden oluşan karar komitesi belirlenir. Problemde $\mathrm{n}$ adet kriterin $(C n, n=1,2, \ldots, n)$ ve karar komitesinde $\mathrm{m}$ tane karar vericinin $(K m, m=1,2, \ldots, m)$ bulunduğu varsayılmaktadır.

2. Aşama: Kriterlerin Önem Sırasının Belirlenmesi: Bu aşamada karar vericiler, kendi bilgileri ve deneyimlerine dayalı olarak kriterleri en iyiden en kötüye doğru önem sırasına göre değerlendirir. Karar probleminde birden fazla karar vericinin olması durumunda, her karar verici kriterleri küçükten büyüğe doğru önem düzeyinde sıralar. Elde edilen sıralamaların geometrik ortalaması alınarak, genel bir siralama elde edilir.

3. Aşama: Kriterlerin Göreli Önem Düzeylerinin Belirlenmesi: Bu aşamda kriterlerin göreli önem düzeylerini belirlemek için, $j$. kriterin $(j+1)$. kritere göre ne kadar daha önemli olduğu belirlenir. Belirlenen bu değer " $\boldsymbol{s}_{\boldsymbol{j}}$ " ile gösterilir ve "ortalama değerin karşılaştırmalı önemi" olarak tanımlanır.

4. Aşama: $\boldsymbol{k}_{\boldsymbol{j}}$ Katsayısının Belirlenmesi: Her kriter için “ $k_{j}$ ” katsayıları, Eşitlik (1)'den yararlanılarak hesaplanır.

$$
k_{j}=\left\{\begin{array}{cc}
1 & \mathrm{j}=1 \\
s_{j}+1 & \mathrm{j}>1
\end{array}\right.
$$


5. Aşama: $\boldsymbol{q}_{j}$ Katsayısının Belirlenmesi: Her kriter için ağırlıkları gösterecek olan " $q_{j}$ " katsayıları, Eşitlik (2)'den yararlanılarak hesaplanır.

$$
q_{j}=\left\{\begin{array}{cc}
1 & \mathrm{j}=1 \\
\frac{q_{j-1}}{s_{j}} & \mathrm{j}>1
\end{array}\right.
$$

6. Aşama: Kriterlerin Göreli Ăğılıklarını Belirlenmesi: Yöntemin son aşamasında, kriterlerin göreli ağırlıkları $\left(w_{j}\right)$ Eşitlik (3)’ten yararlanılarak hesaplanır.

$$
w_{j}=\frac{q_{j}}{\sum_{k=1}^{n} q_{k}}
$$

\section{EDAS}

Keshavarz Ghorabaee vd. tarafindan 2015 yılında literatüre kazandırılan EDAS (Evaluation based on Distance from Average Solution) yöntemi, karar altenatifleri arasından en iyisinin belirlenmesi sürecinde, ortalama çözüm uzaklığına göre hesaplamalar ile değerlendirme yapılan bir yöntemdir. EDAS yöntemi alt1 aşamadan oluşan bir uygulama sürecine sahiptir (Keshavarz Ghorabaee vd., 2015)

1. Aşama: Karar Matrisinin Oluşturulması: Yöntemin ilk aşamasında karar probleminde yer alacak kriterler ve karar alternatifleri belirlenerek, karar matrisi Eşitlik (4)'te gösterilen şekilde oluşturulur. Bu eşitlikteki $x_{i j}$ değerleri, $i$. karar alternatifinin, $j$. kritere göre performansını göstermektedir.

$$
X=\left[X_{i j}\right]_{n \times m}\left[\begin{array}{cccc}
x_{11} & x_{12} & \ldots & x_{1 m} \\
x_{21} & x_{22} & \ldots & x_{2 m} \\
\vdots & \vdots & \ldots & \vdots \\
x_{n 1} & x_{n 2} & \ldots & x_{n m}
\end{array}\right]
$$

2. Aşama: Ortalama Çözüm Matrisinin Elde Edilmesi: Bu aşamada tüm kriter değerlerinin ortalaması alınarak ortalama çözüm matrisi $(A V)$, Eşitlik (5)'te gösterilen şekilde oluşturulur.

$$
A V=\left[A V_{j}\right]_{1 \times m}
$$

Eşitlik (5)'te gösterilen $A V_{j}$ değerleri, j. kriterin ortalamasını göstermekte ve Eşitlik (6) yardımıyla hesaplanmaktadır. 


$$
A V_{j}=\frac{\sum_{i=1}^{n} X_{i j}}{n}
$$

3. Aşama: Ortalamadan Uzaklık Matrislerinin Elde Edilmesi: Bu aşamada her kriter için ortalamadan uzaklıklar, ortalamadan pozitif uzaklık (PDA) ve ortalamadan negatif uzaklık (NDA) olmak üzere iki farklı şekilde ele alınır. Pozitif ve negatif uzaklık matrisleri Eşitlik (7) ve (8)'de gösterilen şekilde oluşturulur.

$$
\begin{aligned}
& P D A=\left[P D A_{i j}\right]_{n \times m} \\
& P D A=\left[P D A_{i j}\right]_{n \times m}
\end{aligned}
$$

Pozitif ve negatif uzaklık matrisindeki değerler, kriterlerin fayda ya da maliyet yönlü olma durumlarına göre farklı şekillerde hesaplanmaktadır. Fayda yönlü kriterler için bu değerler hesaplanırken, Eşitlik (9) ve (10)'dan yararlanılmalıdır.

$$
\begin{aligned}
P D A_{i j} & =\frac{\max \left(0,\left(X_{i j}-A V_{j}\right)\right)}{A V_{j}} \\
N D A_{i j} & =\frac{\max \left(0,\left(A V_{j}-X_{i j}\right)\right)}{A V_{j}}
\end{aligned}
$$

Maliyet yönlü kriterler için ortalamadan pozitif ve negatif uzaklık değerleri Eşitlik (11) ve (12)'den yararlanılarak hesaplanır.

$$
\begin{aligned}
P D A_{i j} & =\frac{\max \left(0,\left(A V_{j}-X_{i j}\right)\right)}{A V_{j}} \\
N D A_{i j} & =\frac{\max \left(0,\left(X_{i j}-A V_{j}\right)\right)}{A V_{j}}
\end{aligned}
$$

4. Aşama: Ăğırlıklı Toplam Değerlerin Elde Edilmesi: Bu aşamada tüm karar alternatifleri için ağırlıklı toplam değerler, ağırlıklı toplam pozitif değer $\left(S P_{i}\right)$ ve ağırlıklı toplam negatif değer $\left(S N_{i}\right)$ olacak şekilde Eşitlik (13) ve (14) yardımıyla hesaplanır.

$$
\begin{gathered}
S P_{i}=\sum_{j=1}^{m} w_{j} \times P D A_{i j} \\
S N_{i}=\sum_{j=1}^{m} w_{j} \times P N D A_{i j}
\end{gathered}
$$

Eşitlik (13) ve (14)’te yer alan $w_{j}$ değerleri, kriterlerin önem ağırlıkları göstermektedir. 
5. Aşama: Ăğırlıklı Toplam Dĕgerlerin Normalizasyonu: Bu aşamada, bir önceki aşamada hesaplanan $\left(S P_{i}\right)$ ile $\left(S N_{i}\right)$ değerleri Eşitlik (15) ve (16)'dan yararlanılarak normalize edilir.

$$
\begin{gathered}
N S P_{i}=\frac{S P_{i}}{\max \left(S P_{i}\right)} \\
N S N_{i}=1-\frac{S N_{i}}{\max \left(S N_{i}\right)}
\end{gathered}
$$

6. Aşama: Değerlendirme Skorlarının Hesaplanması: Yöntemin son aşamasında, her karar alternatifi için değerlendirme skorları $\left(A S_{i}\right)$ Eşitlik (17) yardımıyla hesaplanır.

$$
A S_{i}=\frac{1}{2}\left(S N P_{i}+N S N_{i}\right)
$$

Her karar alternatifi için hesaplanan değerlendirme skorları 0 ile 1 arasında değer alacaktır. Hesaplamalar sonucunda en yüksek skora sahip karar alternatifi en iyi alternatif olarak belirlenecektir.

\section{Uygulama}

Çalışmanın uygulama kısmında öncelikle literatürde yapılan araştırmalar 1şı̆̆ında lojistik performansı değerlendirmeye yönelik kriterler belirlenmiştir. Kriterler belirlendikten sonra SWARA yöntemi ile kriterler ağırlıklandırılmış ve EDAS yöntemi ile OECD ülkelerinin lojistik performansı sıralanmıştır.

\subsection{Lojistik Performans Kriterlerinin Belirlenmesi}

Lojistiğin birçok boyutu olması sebebiyle performansının ölçülmesi de farklı boyutların ele alınmasını gerektirmektedir. Bu çalışmada Dünya Bankası tarafından 2007 yılından itibaren düzenli olarak kapsamlı bir şekilde yayımlanan raporda, ülkeler için belirlenen LPI göstergeleri temel alınmıştır. Birçok alt bileşeni dikkate alan göstergelere ait puanların hesaplanmasında 5'li Likert ölçeği kullanılmış ve lojistik firmaları tarafından yapılan yaklaşık 6000 adet ülke değerlendirmesi dikkate alınmıştır. Sözkonusu göstergeler çalışmanın lojistik performansı değerlendirme kriterlerini temsil etmektedir. LPI verileri yerel hükümetler, bölgesel gruplar ve OECD, Birleşmiş Milletler gibi uluslararası organizasyonlar tarafından da kabul görmüştür (Arvis vd., 2018, s. 31).

Çalışma kapsamında ele alınan lojistik performans kriterleri ve bu kriterlere ilişkin açıklamalar Tablo 1'de özetlenmiştir. 
Tablo 1: Çalışma Kapsamında Ele Alınan Performans Kriterleri

\begin{tabular}{|c|c|}
\hline Kriter Adı & Açıklama \\
\hline $\begin{array}{c}\text { Gümrük } \\
\text { Yönetimi (K1) }\end{array}$ & Sinır ve gümrük yönetimine ilişkin işlemlerin etkin şekilde \\
yürümesi
\end{tabular}

\subsection{SWARA Yöntemi ile Kriter Ăğırlıklarının Belirlenmesi}

Uygulamanın ilk bölümünde bir önceki başlıkta belirlenen lojistik performans kriterlerine ilişkin kriter ağırlıkları SWARA yöntemiyle hesaplanacaktır. Karar verme sürecinde lojistik sektörü temsilcileri ve akademisyenlerden oluşan altı farklı uzman karar vericinin değerlendirmelerine göre önem sıraları belirlenen kriterler ve bu kriterlerin göreli önem düzeyleri Tablo 2'de gösterilmiştir.

Tablo 2: Kriterlerin Önem Sıraları ve Göreli Önem Düzeyleri

\begin{tabular}{|l|l|l|l|l|l|l|l|l|}
\hline \multicolumn{3}{|c|}{ Karar Verici-1 } & \multicolumn{3}{c|}{ Karar Verici-2 } & \multicolumn{3}{c|}{ Karar Verici-3 } \\
\hline $\begin{array}{l}\text { Önem } \\
\text { Sıras1 }\end{array}$ & Kriter & Sj & $\begin{array}{l}\text { Onem } \\
\text { Siras1 }\end{array}$ & Kriter & Sj & $\begin{array}{l}\text { Önem } \\
\text { Siras1 }\end{array}$ & Kriter & Sj \\
\hline 1 & K2 & - & 1 & K2 & - & 1 & K2 & - \\
\hline 2 & K3 & 0.20 & 2 & K4 & 0.10 & 2 & K4 & 0.15 \\
\hline 3 & K4 & 0.10 & 3 & K3 & 0.10 & 3 & K3 & 0.15 \\
\hline 4 & K1 & 0.10 & 4 & K1 & 0.10 & 4 & K6 & 0.10 \\
\hline 5 & K5 & 0.05 & 5 & K5 & 0.10 & 5 & K5 & 0.05 \\
\hline 6 & K6 & 0.05 & 6 & K6 & 0.10 & 6 & K1 & 0.05 \\
\hline \multicolumn{3}{|c|}{ Karar Verici-4 } & \multicolumn{3}{|c|}{ Karar Verici-5 } & \multicolumn{3}{c|}{ Karar Verici-6 } \\
\hline Önem & Kriter & Sj & Önem & Kriter & Sj & Önem & Kriter & Sj \\
Siras1 & & & S1ras1 & & & S1ras1 & & K4 \\
\hline 1 & K2 & - & 1 & K4 & - & 1 & - \\
\hline 2 & K4 & 0.10 & 2 & K6 & 0.30 & 2 & K4 & 0.15 \\
\hline 3 & K3 & 0.15 & 3 & K3 & 0.20 & 3 & K2 & 0.05 \\
\hline 4 & K1 & 0.05 & 4 & K2 & 0.15 & 4 & K6 & 0.10 \\
\hline 5 & K6 & 0.15 & 5 & K1 & 0.15 & 5 & K1 & 0.20 \\
\hline 6 & K5 & 0.10 & 6 & K5 & 0.10 & 6 & K5 & 0.15 \\
\hline
\end{tabular}

Kriterlerin göreli önem düzeyleri belirlendikten sonra her karar verici için ayrı ayrı kriterlerin göreli ağırlıkları Eşitlik (1)-(3)'ten yararlanılarak hesaplanmıştır. Tablo 3'te karar verici-1 için örnek bir hesaplamaya yer verilmiştir. 
Tablo 3: Karar Verici-1 İçin Hesaplamalar

\begin{tabular}{|c|l|c|c|c|c|}
\hline \multicolumn{7}{|c|}{ Karar Verici-1 } \\
\hline $\begin{array}{c}\text { Önem } \\
\text { Sirası }\end{array}$ & Kriter & $\mathbf{s j}$ & $\mathbf{k j}$ & $\mathbf{q j}$ & $\mathbf{w j}$ \\
\hline 1 & K2 & - & 1 & 1.000 & 0.219 \\
\hline 2 & K3 & 0.20 & 1.20 & 0.833 & 0.183 \\
\hline 3 & K4 & 0.10 & 1.10 & 0.758 & 0.166 \\
\hline 4 & K1 & 0.10 & 1.10 & 0.689 & 0.151 \\
\hline 5 & K5 & 0.05 & 1.05 & 0.656 & 0.144 \\
\hline 6 & K6 & 0.05 & 1.05 & 0.625 & 0.137 \\
\hline
\end{tabular}

Karar verici-1 için Tablo 3'te gösterilen örnek hesaplamalar, tüm karar vericiler için tekrarlanmıştır. SWARA yöntemi ile her karar verici için hesaplanan kriter ağırlıklarının geometrik ortalamaları alınarak nihai kriter ağırlıkları belirlenmiştir. Tablo 4'te SWARA yöntemiyle hesaplanan kriter ağırlıkları gösterilmiştir.

Tablo 4: SWARA Yöntemiyle Belirlenen Kriter Ăğırlıkları

\begin{tabular}{|c|c|c|c|c|c|c|c|c|}
\hline Kriter & KV-1 & KV-2 & KV-3 & KV-4 & KV-5 & KV-6 & $\begin{array}{c}\text { Nihai } \\
\text { Ă̆Irlı }\end{array}$ & Siralama \\
\hline K1 & 0.151 & 0.157 & 0.136 & 0.160 & 0.125 & 0.118 & $\mathbf{0 . 1 4 0}$ & 5 \\
\hline K2 & 0.219 & 0.209 & 0.218 & 0.213 & 0.143 & 0.179 & $\mathbf{0 . 1 9 5}$ & 2 \\
\hline K3 & 0.183 & 0.173 & 0.165 & 0.168 & 0.165 & 0.188 & $\mathbf{0 . 1 7 3}$ & 3 \\
\hline K4 & 0.166 & 0.190 & 0.189 & 0.193 & 0.257 & 0.216 & $\mathbf{0 . 2 0 0}$ & 1 \\
\hline K5 & 0.144 & 0.143 & 0.143 & 0.127 & 0.113 & 0.136 & $\mathbf{0 . 1 3 4}$ & 6 \\
\hline K6 & 0.137 & 0.130 & 0.150 & 0.139 & 0.198 & 0.163 & $\mathbf{0 . 1 5 1}$ & 4 \\
\hline
\end{tabular}

Tablo 4'te gösterilen SWARA yöntemi sonuçlarına göre, K4-lojistik hizmet kalitesi $(0,200)$ en önemli kriter olarak belirlenmiştir. Lojistik hizmet kalitesi kriterini sırasıyla K2-altyap1 $(0,195)$ ve K3-uluslararası sevkiyat $(0,173)$ kriterleri takip etmektedir.

\subsection{EDAS Yöntemi ile Ülkelerin Lojistik Performanslarının Değerlendirilmesi}

SWARA yöntemiyle kriter ağırlıkları hesaplandıktan sonra, EDAS yöntemiyle OECD ülkelerinin lojistik performansları değerlendirilecektir. 36 ülkenin yer alacağı karar matrisinde, ortalama çözüm uzaklığına göre hesaplamalar yapması bakımından EDAS yöntemi tercih edilmiştir. Ayrıca lojistik performansının değerlendirilmesinde EDAS yöntemi ile gerçekleştirilen herhangi bir çalışmaya rastlanılmaması bakımından mevcut çalışmanın literatüre katkı sağlayacağ1 düşünülmektedir. Ülkelerin ele alınan performans kriterlerine ait puanları, Dünya Bankası (2018) raporunda yer alan 2012, 2014, 2016 ve 2018 yıllarında yapılan değerlendirmelere ilişkin bütünleştirilmiş sonuçlardan elde edilmiştir. 36 OECD ülkesine ilişkin elde edilen verilerden oluşan karar matrisi Tablo 5'te gösterilmiştir. 
Tablo 5: Karar Matrisi

\begin{tabular}{|l|c|c|c|c|c|c|}
\hline & K1 & K2 & K3 & K4 & K5 & K6 \\
\hline ABD & 3.76 & 4.10 & 3.54 & 3.93 & 4.13 & 4.14 \\
\hline Almanya & 4.09 & 4.38 & 3.83 & 4.26 & 4.22 & 4.40 \\
\hline Avustralya & 3.76 & 3.92 & 3.40 & 3.76 & 3.83 & 4.00 \\
\hline Avusturya & 3.71 & 4.07 & 3.78 & 4.04 & 4.13 & 4.22 \\
\hline Belçika & 3.74 & 4.03 & 3.97 & 4.10 & 4.11 & 4.40 \\
\hline Çekya & 3.34 & 3.38 & 3.65 & 3.65 & 3.68 & 3.98 \\
\hline Danimarka & 3.88 & 3.89 & 3.59 & 3.98 & 3.94 & 4.26 \\
\hline Estonya & 3.30 & 3.13 & 3.19 & 3.15 & 3.20 & 3.80 \\
\hline Finlandiya & 3.89 & 3.95 & 3.56 & 3.88 & 4.10 & 4.17 \\
\hline Fransa & 3.63 & 4.00 & 3.60 & 3.82 & 3.99 & 4.17 \\
\hline Hollanda & 3.97 & 4.23 & 3.76 & 4.12 & 4.08 & 4.30 \\
\hline İngiltere & 3.85 & 4.09 & 3.69 & 4.04 & 4.10 & 4.32 \\
\hline İrlanda & 3.45 & 3.50 & 3.53 & 3.69 & 3.79 & 3.85 \\
\hline İspanya & 3.57 & 3.79 & 3.72 & 3.78 & 3.78 & 4.04 \\
\hline İsrail & 3.32 & 3.33 & 2.93 & 3.44 & 3.50 & 3.89 \\
\hline İsveç & 3.95 & 4.22 & 3.88 & 4.04 & 4.02 & 4.32 \\
\hline İsviçre & 3.75 & 4.07 & 3.57 & 3.92 & 4.02 & 4.20 \\
\hline İtalya & 3.44 & 3.82 & 3.55 & 3.68 & 3.84 & 4.09 \\
\hline İzlanda & 3.02 & 3.18 & 3.00 & 3.48 & 3.38 & 3.72 \\
\hline Japonya & 3.91 & 4.19 & 3.61 & 4.03 & 4.03 & 4.24 \\
\hline Kanada & 3.70 & 3.91 & 3.45 & 3.90 & 3.91 & 4.03 \\
\hline Kore & 3.43 & 3.75 & 3.43 & 3.63 & 3.75 & 3.96 \\
\hline Letonya & 2.93 & 3.03 & 2.97 & 2.92 & 3.06 & 3.25 \\
\hline Litvanya & 3.02 & 3.00 & 3.03 & 3.10 & 3.25 & 3.78 \\
\hline Lüksemburg & 3.67 & 3.84 & 3.68 & 3.83 & 3.78 & 4.27 \\
\hline Macaristan & 3.18 & 3.31 & 3.29 & 3.27 & 3.61 & 3.82 \\
\hline Meksika & 2.78 & 2.90 & 3.09 & 3.06 & 3.14 & 3.49 \\
\hline Norveç & 3.62 & 3.84 & 3.48 & 3.75 & 3.83 & 3.96 \\
\hline Polonya & 3.26 & 3.17 & 3.57 & 3.49 & 3.49 & 3.94 \\
\hline Portekiz & 3.24 & 3.23 & 3.59 & 3.54 & 3.69 & 4.03 \\
\hline Slovakya & 2.94 & 3.09 & 3.19 & 3.13 & 3.02 & 3.45 \\
\hline Slovenya & 3.21 & 3.25 & 3.16 & 3.17 & 3.30 & 3.65 \\
\hline Şili & 3.23 & 3.09 & 3.24 & 3.09 & 3.30 & 3.73 \\
\hline Türkiye & 2.94 & 3.36 & 3.19 & 3.23 & 3.37 & 3.68 \\
\hline Yeni Zelanda & 3.58 & 3.79 & 3.27 & 3.69 & 3.73 & 4.10 \\
\hline Yunanistan & 2.88 & 3.19 & 3.13 & 3.02 & 3.25 & 3.67 \\
\hline & & & & & & \\
\hline
\end{tabular}

Her kriter için ortalama çözüm değerleri Eşitlik (5) yardımıyla elde edilerek Tablo 6'da gösterilmiştir.

Tablo 6: Ortalama Çözüm Değerleri

\begin{tabular}{|c|c|c|c|c|c|c|}
\hline & K1 & K2 & K3 & K4 & K5 & K6 \\
\hline $\mathbf{A V j}$ & 3.47 & 3.64 & 3.45 & 3.63 & 3.70 & 3.98 \\
\hline
\end{tabular}


Bir sonraki aşamada her kriter için ortalamadan uzaklıklar hesaplanacaktır. Verilerin alındığı raporda yer alan ülkelerin kriterlere ait puanları 5'li ölçek üzerinde değerlendirildiğinden dolayı, tüm kriterler fayda yönlü olarak dikkate alınarak hesaplamalar gerçekleştirilmiştir. Ortalamadan pozitif uzaklık (PDA) değerleri Eşitlik (9)'dan yararlanılarak Tablo 7'de gösterilen şekilde elde edilmiştir.

Tablo 7: Ortalamadan Pozitif Uzaklık Değerleri

\begin{tabular}{|l|c|c|c|c|c|c|}
\hline & K1 & K2 & K3 & K4 & K5 & K6 \\
\hline ABD & 0.083 & 0.127 & 0.027 & 0.083 & 0.115 & 0.04 \\
\hline Almanya & 0.178 & 0.203 & 0.111 & 0.174 & 0.139 & 0.105 \\
\hline Avustralya & 0.083 & 0.077 & 0 & 0.036 & 0.034 & 0.005 \\
\hline Avusturya & 0.069 & 0.118 & 0.096 & 0.114 & 0.115 & 0.06 \\
\hline Belçika & 0.078 & 0.107 & 0.152 & 0.13 & 0.11 & 0.105 \\
\hline Çekya & 0 & 0 & 0.059 & 0.006 & 0 & 0 \\
\hline Danimarka & 0.118 & 0.069 & 0.041 & 0.097 & 0.064 & 0.07 \\
\hline Estonya & 0 & 0 & 0 & 0 & 0 & 0 \\
\hline Finlandiya & 0.121 & 0.085 & 0.033 & 0.069 & 0.107 & 0.047 \\
\hline Fransa & 0.046 & 0.099 & 0.044 & 0.053 & 0.077 & 0.047 \\
\hline Hollanda & 0.144 & 0.162 & 0.091 & 0.136 & 0.101 & 0.08 \\
\hline İngiltere & 0.109 & 0.124 & 0.07 & 0.114 & 0.107 & 0.085 \\
\hline İrlanda & 0 & 0 & 0.024 & 0.017 & 0.023 & 0 \\
\hline İspanya & 0.029 & 0.041 & 0.079 & 0.042 & 0.02 & 0.015 \\
\hline İsrail & 0 & 0 & 0 & 0 & 0 & 0 \\
\hline İsveç & 0.138 & 0.16 & 0.125 & 0.114 & 0.085 & 0.085 \\
\hline İsviçre & 0.081 & 0.118 & 0.036 & 0.08 & 0.085 & 0.055 \\
\hline İtalya & 0 & 0.05 & 0.03 & 0.014 & 0.037 & 0.027 \\
\hline İzlanda & 0 & 0 & 0 & 0 & 0 & 0 \\
\hline Japonya & 0.127 & 0.151 & 0.047 & 0.111 & 0.088 & 0.065 \\
\hline Kanada & 0.066 & 0.074 & 0.001 & 0.075 & 0.056 & 0.012 \\
\hline Kore & 0 & 0.03 & 0 & 0.001 & 0.012 & 0 \\
\hline Letonya & 0 & 0 & 0 & 0 & 0 & 0 \\
\hline Litvanya & 0 & 0 & 0 & 0 & 0 & 0 \\
\hline Lüksemburg & 0.057 & 0.055 & 0.067 & 0.056 & 0.02 & 0.073 \\
\hline Macaristan & 0 & 0 & 0 & 0 & 0 & 0 \\
\hline Meksika & 0 & 0 & 0 & 0 & 0 & 0 \\
\hline Norveç & 0.043 & 0.055 & 0.009 & 0.034 & 0.034 & 0 \\
\hline Polonya & 0 & 0 & 0.036 & 0 & 0 & 0 \\
\hline Portekiz & 0 & 0 & 0.041 & 0 & 0 & 0.012 \\
\hline Slovakya & 0 & 0 & 0 & 0 & 0 & 0 \\
\hline Slovenya & 0 & 0 & 0 & 0 & 0 & 0 \\
\hline Sili & 0 & 0 & 0 & 0 & 0 & 0 \\
\hline Türkiye & 0 & 0 & 0 & 0 & 0 & 0 \\
\hline Yeni Zelanda & 0.032 & 0.041 & 0 & 0.017 & 0.007 & 0.03 \\
\hline Yunanistan & 0 & 0 & 0 & 0 & 0 & 0 \\
\hline & & & & & & \\
\hline
\end{tabular}

Ortalamadan negatif uzaklık (NDA) değerleri ise Eşitlik (10)'dan yararlanılarak Tablo 8'de gösterilen şekilde elde edilmiştir. 
Tablo 8: Ortalamadan Negatif Uzaklık Değerleri

\begin{tabular}{|l|c|c|c|c|c|c|}
\hline & K1 & $\mathbf{K 2}$ & $\mathbf{K 3}$ & $\mathbf{K 4}$ & $\mathbf{K 5}$ & $\mathbf{K 6}$ \\
\hline ABD & 0 & 0 & 0 & 0 & 0 & 0 \\
\hline Almanya & 0 & 0 & 0 & 0 & 0 & 0 \\
\hline Avustralya & 0 & 0 & 0.014 & 0 & 0 & 0 \\
\hline Avusturya & 0 & 0 & 0 & 0 & 0 & 0 \\
\hline Belçika & 0 & 0 & 0 & 0 & 0 & 0 \\
\hline Çekya & 0.038 & 0.071 & 0 & 0 & 0.007 & 0 \\
\hline Danimarka & 0 & 0 & 0 & 0 & 0 & 0 \\
\hline Estonya & 0.049 & 0.14 & 0.075 & 0.132 & 0.136 & 0.045 \\
\hline Finlandiya & 0 & 0 & 0 & 0 & 0 & 0 \\
\hline Fransa & 0 & 0 & 0 & 0 & 0 & 0 \\
\hline Hollanda & 0 & 0 & 0 & 0 & 0 & 0 \\
\hline İngiltere & 0 & 0 & 0 & 0 & 0 & 0 \\
\hline İrlanda & 0.006 & 0.038 & 0 & 0 & 0 & 0.033 \\
\hline İspanya & 0 & 0 & 0 & 0 & 0 & 0 \\
\hline İsrail & 0.043 & 0.085 & 0.15 & 0.052 & 0.055 & 0.023 \\
\hline İsveç & 0 & 0 & 0 & 0 & 0 & 0 \\
\hline İsviçre & 0 & 0 & 0 & 0 & 0 & 0 \\
\hline İtalya & 0.009 & 0 & 0 & 0 & 0 & 0 \\
\hline İzlanda & 0.13 & 0.126 & 0.13 & 0.041 & 0.088 & 0.066 \\
\hline Japonya & 0 & 0 & 0 & 0 & 0 & 0 \\
\hline Kanada & 0 & 0 & 0 & 0 & 0 & 0 \\
\hline Kore & 0.012 & 0 & 0.005 & 0 & 0 & 0.005 \\
\hline Letonya & 0.156 & 0.167 & 0.139 & 0.195 & 0.174 & 0.184 \\
\hline Litvanya & 0.13 & 0.176 & 0.121 & 0.146 & 0.123 & 0.051 \\
\hline Lüksemburg & 0 & 0 & 0 & 0 & 0 & 0 \\
\hline Macaristan & 0.084 & 0.091 & 0.046 & 0.099 & 0.025 & 0.04 \\
\hline Meksika & 0.199 & 0.203 & 0.104 & 0.157 & 0.152 & 0.123 \\
\hline Norveç & 0 & 0 & 0 & 0 & 0 & 0.005 \\
\hline Polonya & 0.061 & 0.129 & 0 & 0.038 & 0.058 & 0.01 \\
\hline Portekiz & 0.066 & 0.113 & 0 & 0.024 & 0.004 & 0 \\
\hline Slovakya & 0.153 & 0.151 & 0.075 & 0.137 & 0.185 & 0.133 \\
\hline Slovenya & 0.075 & 0.107 & 0.083 & 0.126 & 0.109 & 0.083 \\
\hline Şili & 0.069 & 0.151 & 0.06 & 0.148 & 0.109 & 0.063 \\
\hline Türkiye & 0.153 & 0.077 & 0.075 & 0.11 & 0.09 & 0.076 \\
\hline Yeni Zelanda & 0 & 0 & 0.051 & 0 & 0 & 0 \\
\hline Yunanistan & 0.17 & 0.123 & 0.092 & 0.168 & 0.123 & 0.078 \\
\hline & & & & & & \\
\hline
\end{tabular}

Ortalamadan uzaklık değerleri elde edildikten sonra tüm ülkeler için ağırlıklı toplam değerler hesaplanmalıdır. Bu hesaplamayı yapabilmek için uygulamanın ilk bölümünde SWARA yöntemiyle Tablo 4'te gösterilen şekilde hesaplanan kriterlerin önem ağırlıkları bu aşamada EDAS yöntemine dahil edilmiştir.

Ağırlıklandırılmış toplam pozitif değerler $\left(S P_{i}\right)$ Eşitlik (13) yardımıyla hesaplandıktan sonra, Eşitlik (15) yardımıyla bu toplam değerler normalize edilir. Ağırlıklı toplam pozitif değerler ve normalizasyonu Tablo 9'da gösterilmiştir. 
Tablo 9: Ortalamadan Pozitif Uzaklık Değerlerinin Ağırlıklandırılmış Toplamları ve Normalizasyonu

\begin{tabular}{|c|c|c|c|c|c|c|c|c|}
\hline & K1 & K2 & K3 & K4 & K5 & K6 & $\mathbf{S P i}$ & NSPi \\
\hline ABD & 0.012 & 0.025 & 0.005 & 0.017 & 0.015 & 0.006 & 0.079 & 0.516 \\
\hline Almanya & 0.025 & 0.04 & 0.019 & 0.035 & 0.019 & 0.016 & 0.153 & 1 \\
\hline Avustralya & 0.012 & 0.015 & 0 & 0.007 & 0.005 & 0.001 & \begin{tabular}{|l|}
0.039 \\
\end{tabular} & 0.256 \\
\hline Avusturya & 0.01 & 0.023 & 0.017 & 0.023 & 0.015 & 0.009 & \begin{tabular}{|l|}
0.097 \\
\end{tabular} & 0.63 \\
\hline Belçika & 0.011 & 0.021 & 0.026 & 0.026 & 0.015 & 0.016 & 0.115 & 0.748 \\
\hline Çekya & 0 & 0 & 0.01 & 0.001 & 0 & 0 & 0.011 & 0.074 \\
\hline Danimarka & .017 & 0.013 & 0.007 & 0.019 & 0.009 & 0.011 & 0.076 & 0.493 \\
\hline Estonya & 0 & 0 & 0 & 0 & 0 & 0 & 0 & 0 \\
\hline Finlandiya & .017 & 0.017 & 0.006 & 0.014 & 0.014 & 0.007 & 0.075 & 0.487 \\
\hline Fransa & 0.006 & 0.019 & 0.008 & 0.011 & 0.01 & 0.007 & 0.061 & 0.401 \\
\hline Hollanda & 0.02 & 0.032 & 0.016 & 0.027 & 0.014 & 0.012 & 0.12 & 0.785 \\
\hline İngiltere & 0.015 & 0.024 & 0.012 & 0.023 & 0.014 & 0.013 & 0.101 & 0.662 \\
\hline İrlanda & 0 & 0 & 0.004 & 0.003 & 0.003 & 0 & 0.011 & 0.07 \\
\hline İspanya & 0.004 & 0.008 & 0.014 & 0.008 & 0.003 & 0.002 & 0.039 & 0.255 \\
\hline İsrail & 0 & 0 & 0 & 0 & 0 & 0 & 0 & 0 \\
\hline İsveç & 0.019 & 0.031 & 0.022 & 0.023 & 0.011 & 0.013 & 0.119 & 0.777 \\
\hline İsviçre & 0.011 & 0.023 & 0.006 & 0.016 & 0.011 & 0.008 & 0.076 & 0.498 \\
\hline İtalya & 0 & 0.01 & 0.005 & 0.003 & 0.005 & 0.004 & 0.027 & 0.174 \\
\hline İzlanda & 0 & 0 & 0 & 0 & 0 & 0 & 0 & 0 \\
\hline Japonya & 0.018 & 0.029 & 0.008 & 0.022 & 0.012 & 0.01 & 0.099 & 0.647 \\
\hline Kanada & 0.009 & 0.014 & 0 & 0.015 & 0.007 & 0.002 & 0.048 & 0.314 \\
\hline Kore & 0 & 0.006 & 0 & 0 & 0.002 & 0 & 0.008 & 0.05 \\
\hline Letony & 0 & 0 & 0 & 0 & 0 & 0 & 0 & 0 \\
\hline Litvany & 0 & 0 & 0 & 0 & 0 & 0 & 0 & 0 \\
\hline Lüksemburg & 0.008 & 0.011 & 0.012 & 0.011 & 0.003 & 0.011 & 0.055 & 0.361 \\
\hline Macaristan & 0 & 0 & 0 & 0 & 0 & 0 & 0 & 0 \\
\hline Meksika & 0 & 0 & 0 & 0 & 0 & 0 & 0 & 0 \\
\hline Norveç & 0.006 & 0.011 & 0.002 & 0.007 & 0.005 & 0 & 0.03 & 0.194 \\
\hline Polonya & 0 & 0 & 0.006 & 0 & 0 & 0 & 0.006 & 0.04 \\
\hline Portekiz & 0 & 0 & 0.007 & 0 & 0 & 0.002 & \begin{tabular}{|l|}
0.009 \\
\end{tabular} & 0.059 \\
\hline Slovakya & 0 & 0 & 0 & 0 & 0 & 0 & 0 & 0 \\
\hline Slovenya & 0 & 0 & 0 & 0 & 0 & 0 & 0 & 0 \\
\hline Şili & 0 & 0 & 0 & 0 & 0 & 0 & 0 & 0 \\
\hline Türkiye & 0 & 0 & 0 & 0 & 0 & 0 & 0 & 0 \\
\hline Yeni Zelanda & 0.004 & 0.008 & 0 & 0.003 & 0.001 & 0.005 & 0.021 & 0.139 \\
\hline Yunanistan & 0 & 0 & 0 & 0 & 0 & 0 & 0 & 0 \\
\hline
\end{tabular}

Ağırlıklandırılmış toplam negatif değerler $\left(S N_{i}\right)$ ise Eşitlik (14) yardımıyla hesaplandıktan sonra, Eşitlik (16) yardımıyla bu toplam değerler normalize edilir. Ağırlıklandırılmış toplam negatif değerler ve normalizasyonu Tablo 10'da gösterilmiştir. 
Tablo 10: Ortalamadan Negatif Uzaklık Değerlerinin Ağırlıklandırılmış Toplamları ve Normalizasyonu

\begin{tabular}{|l|c|c|c|c|c|c|c|c|}
\hline & $\mathbf{K 1}$ & $\mathbf{K 2}$ & $\mathbf{K 3}$ & $\mathbf{K 4}$ & $\mathbf{K 5}$ & $\mathbf{K 6}$ & $\mathbf{S N i}$ & $\mathbf{N S N i}$ \\
\hline ABD & 0 & 0 & 0 & 0 & 0 & 0 & 0 & 1 \\
\hline Almanya & 0 & 0 & 0 & 0 & 0 & 0 & 0 & 1 \\
\hline Avustralya & 0 & 0 & 0.002 & 0 & 0 & 0 & 0.002 & 0.986 \\
\hline Avusturya & 0 & 0 & 0 & 0 & 0 & 0 & 0 & 1 \\
\hline Belçika & 0 & 0 & 0 & 0 & 0 & 0 & 0 & 1 \\
\hline Çekya & 0.005 & 0.014 & 0 & 0 & 0.001 & 0 & 0.02 & 0.881 \\
\hline Danimarka & 0 & 0 & 0 & 0 & 0 & 0 & 0 & 1 \\
\hline Estonya & 0.007 & 0.027 & 0.013 & 0.026 & 0.018 & 0.007 & 0.099 & 0.415 \\
\hline Finlandiya & 0 & 0 & 0 & 0 & 0 & 0 & 0 & 1 \\
\hline Fransa & 0 & 0 & 0 & 0 & 0 & 0 & 0 & 1 \\
\hline Hollanda & 0 & 0 & 0 & 0 & 0 & 0 & 0 & 1 \\
\hline İngiltere & 0 & 0 & 0 & 0 & 0 & 0 & 0 & 1 \\
\hline İrlanda & 0.001 & 0.007 & 0 & 0 & 0 & 0.005 & 0.013 & 0.921 \\
\hline İspanya & 0 & 0 & 0 & 0 & 0 & 0 & 0 & 1 \\
\hline İsrail & 0.006 & 0.017 & 0.026 & 0.01 & 0.007 & 0.003 & 0.07 & 0.586 \\
\hline İsveç & 0 & 0 & 0 & 0 & 0 & 0 & 0 & 1 \\
\hline İsviçre & 0 & 0 & 0 & 0 & 0 & 0 & 0 & 1 \\
\hline İtalya & 0.001 & 0 & 0 & 0 & 0 & 0 & 0.001 & 0.993 \\
\hline İzlanda & 0.018 & 0.025 & 0.022 & 0.008 & 0.012 & 0.01 & 0.095 & 0.436 \\
\hline Japonya & 0 & 0 & 0 & 0 & 0 & 0 & 0 & 1 \\
\hline Kanada & 0 & 0 & 0 & 0 & 0 & 0 & 0 & 1 \\
\hline Kore & 0.002 & 0 & 0.001 & 0 & 0 & 0.001 & 0.003 & 0.98 \\
\hline Letonya & 0.022 & 0.033 & 0.024 & 0.039 & 0.023 & 0.028 & 0.168 & 0 \\
\hline Litvanya & 0.018 & 0.034 & 0.021 & 0.029 & 0.016 & 0.008 & 0.127 & 0.249 \\
\hline Lüksemburg & 0 & 0 & 0 & 0 & 0 & 0 & 0 & 1 \\
\hline Macaristan & 0.012 & 0.018 & 0.008 & 0.02 & 0.003 & 0.006 & 0.067 & 0.605 \\
\hline Meksika & 0.028 & 0.04 & 0.018 & 0.031 & 0.02 & 0.019 & 0.156 & 0.075 \\
\hline Norveç & 0 & 0 & 0 & 0 & 0 & 0.001 & 0.001 & 0.995 \\
\hline Polonya & 0.008 & 0.025 & 0 & 0.008 & 0.008 & 0.002 & 0.051 & 0.7 \\
\hline Portekiz & 0.009 & 0.022 & 0 & 0.005 & 0.001 & 0 & 0.037 & 0.783 \\
\hline Slovakya & 0.021 & 0.029 & 0.013 & 0.027 & 0.025 & 0.02 & 0.136 & 0.192 \\
\hline Slovenya & 0.011 & 0.021 & 0.014 & 0.025 & 0.015 & 0.013 & 0.098 & 0.417 \\
\hline Şili & 0.01 & 0.029 & 0.01 & 0.03 & 0.015 & 0.01 & 0.103 & 0.387 \\
\hline Türkiye & 0.021 & 0.015 & 0.013 & 0.022 & 0.012 & 0.011 & 0.095 & 0.438 \\
\hline Yeni Zelanda & 0 & 0 & 0.009 & 0 & 0 & 0 & 0.009 & 0.947 \\
\hline Yunanistan & 0.024 & 0.024 & 0.016 & 0.034 & 0.016 & 0.012 & 0.126 & 0.255 \\
\hline & & & & & & & & \\
\hline
\end{tabular}

EDAS yönteminin son aşamasında her bir ülke için değerlendirme skorları $\left(A S_{i}\right)$ Eşitlik (17)'den yararlanılarak hesaplanmıştır. Ülkelere ilişkin değerlendirme skorları ve ülkelerin lojistik performanslarına göre elde edilen sıralamaları Tablo 11 'de gösterilmiştir. 
Tablo 11: EDAS Yöntemi Sonuçları ve Ülkelerin Sıralaması

\begin{tabular}{|l|c|c|}
\hline & $\mathbf{A S i}$ & Sıralama \\
\hline ABD & 0.758 & 8 \\
\hline Almanya & 1 & $\mathbf{1}$ \\
\hline Avustralya & 0.621 & 16 \\
\hline Avusturya & 0.815 & 7 \\
\hline Belçika & 0.874 & 4 \\
\hline Çekya & 0.477 & 22 \\
\hline Danimarka & 0.747 & 10 \\
\hline Estonya & 0.208 & 30 \\
\hline Finlandiya & 0.743 & 11 \\
\hline Fransa & 0.701 & 12 \\
\hline Hollanda & 0.892 & $\mathbf{2}$ \\
\hline İngiltere & 0.831 & 5 \\
\hline İlanda & 0.495 & 21 \\
\hline İspanya & 0.628 & 15 \\
\hline İsrail & 0.293 & 26 \\
\hline İsveç & 0.889 & $\mathbf{3}$ \\
\hline İsviçre & 0.749 & 9 \\
\hline İtalya & 0.584 & 18 \\
\hline İzlanda & 0.218 & 28 \\
\hline Japonya & 0.823 & 6 \\
\hline Kanada & 0.657 & 14 \\
\hline Kore & 0.515 & 20 \\
\hline Letonya & 0 & 36 \\
\hline Litvanya & 0.124 & 33 \\
\hline Lüksemburg & 0.68 & 13 \\
\hline Macaristan & 0.303 & 25 \\
\hline Meksika & 0.038 & 35 \\
\hline Norveç & 0.594 & 17 \\
\hline Polonya & 0.37 & 24 \\
\hline Portekiz & 0.421 & 23 \\
\hline Slovakya & 0.096 & 34 \\
\hline Slovenya & 0.208 & 29 \\
\hline Şili & 0.193 & 31 \\
\hline Türkiye & 0.219 & 27 \\
\hline Yeni Zelanda & 0.543 & 19 \\
\hline Yunanistan & 0.127 & 32 \\
\hline & & \\
\hline
\end{tabular}

SWARA ve EDAS yöntemlerinin bütünleşik olarak uygulandığı, OECD ülkelerinin lojistik performanslarının değerlendirildiği çalışmanın sonuçları Tablo 11 'de gösterilmiştir. Elde edilen sonuçlara göre lojistik performansı en yüksek olan ülkenin Almanya olduğu tespit edilmiştir. Almanya'yı sırasıyla Hollanda ve İsveç takip etmektedir. Lojistik performansı en düşük olan ülkelerin ise sırasıyla Letonya, Meksika ve Slovakya olduğu görülmüştür. 


\section{Sonuç ve Öneriler}

Lojistik performansın ölçülmesi ülkelerin ticaret hacimlerinin artması, büyüme ve rekabet gücü elde edebilmesi bakımından önem kazanmıştır. Son yıllarda yapılan araştırmalar lojistik sektörünün etkinliğinin ülkelerin gelişmişlik düzeyine olan etkisini de ortaya koymaktadır.

$\mathrm{Bu}$ çalışmada OECD ülkelerinin lojistik performanslarının değerlendirilmesinde ÇKKV yöntemlerinden bütünleşik olarak yararlanılmıştır. Dünya Bankası LPI raporlarından elde edilen veriler ile uygulama kapsamındaki 36 ülkenin lojistik performans değerleri, her performans değerlendirme kriteri için elde edilmiştir. Uygulamanın ilk bölümünde performans değerlendirme kriterlerine ilişkin önem ağırlıkları, uzman görüşüne dayalı bir yöntem olan SWARA ile hesaplanmıştır. SWARA yöntemi sonuçlarına göre en önemli kriterler lojistik hizmet kalitesi, altyapı ve uluslararası sevkiyat olarak belirlenmiştir. Uygulamanın ikinci bölümünde, SWARA ile elde edilen kriterlerin önem ağırlıkları EDAS yöntemi ile birlikte ele alınarak, ülkelerin performanslarının değerlendirilmesinde ve sıralanmasında kullanılmıştır. Lojistik performansın değerlendirilmesinde EDAS yöntemi ile ilgili herhangi bir çalışmaya rastlanmaması nedeniyle bu yöntem tercih edilerek literatüre katkı sağlamak hedeflenmiştir. EDAS yöntemi sonuçlarına göre lojistik performansı en yüksek olan ülkeler sırasıyla Almanya, Hollanda ve İsveç olarak tespit edilmiştir. En önemli kriterler bazında değerlendirildiğinde lojistik performansı yüksek ülkelerin bu kriterlere ait puanlarının da oldukça yüksek olduğu yani bu ülkelerin lojistik hizmetlerinin kaliteli, lojistik altyapılarının gelişmiş olduğu ve uluslararası sevkiyatları düzenlemede etkin oldukları gözlemlenmektedir.

Çalışmada elde edilen sıralama sonuçlarına göre Türkiye 27. sırada yer almıştır. Türkiye'nin büyüme hedefleri dikkate alındığında bu durum ülkemiz lojistik sektörü açısından tatmin edici değildir. Özellikle OECD ülkeleri arasında GSYİH büyümesi bakımından önemli bir yerde bulunan Türkiye lojistiğin ekonomiye olan etkisini ön planda tutmalıdır. Bu kapsamda lojistik hizmetler gibi katma değeri yüksek alanların kalitesinin arttırılması, hizmetlerin çeşitlendirilerek taşımacılık altyapısının güçlendirilmesi ve lojistik maliyetlerin düşürülmesi hususunda adımlar atılmalıdır. Buna ek olarak lojistik performans göstergeleri arasında Türkiye'nin en düşük puanının gümrük yönetimi konusundaki işlemlerin etkin yürütülmesi ile ilgili olduğu görülmektedir. Türkiye'nin coğrafi konum avantajı da dikkate alınarak oluşturulacak Lojistik Master Planları ve yol haritaları lojistik performansının yükselmesine de katkıda bulunacaktır.

Ayrıca 10. Kalkınma Planı (2014- 2018) “Taşımacılıktan Lojistiğe Dönüşüm Programı" çerçevesinde lojistiğin ülkemizin büyüme potansiyeline etkisinin artırılması ve Türkiye'nin Lojistik Performans Indeksi'nde ilk 15 ülke arasına 
girmesi amaçlanmıştır. Ancak hem dünyada hem de OECD ülkeleri arasında bu hedefin gerisinde olduğu görülmektedir. $\mathrm{Bu}$ amaçlar doğrultusunda uluslarası düzeyde yapılacak değerlendirmelerin, kurulacak işbirliklerinin ve araştırmaların önemi büyük olacaktır. Gelecek çalışmalarda faklı ÇKKV teknikleri veya analiz yöntemleri ile lojistik sektörüne ilişkin performans değerlendirmeleri yapılabilir. Daha fazla gösterge veya kriter dikkate alınarak ülkelerin ya da bölgelerin lojistik performansları ölçülerek bu kapsamda çözüm önerilerinde bulunulabilir.

\section{Kaynaklar}

Adalı, E. A. ve Işık, A. T. (2017). Bir tedarikçi seçim problemi için SWARA ve WASPAS yöntemlerine dayanan karar verme yaklaşımı. International Review of Economics and Management, 5(4), 56-77.

Agility (2018). Agility emerging markets logistics index 2018. https://www.agility.com/wp-content/uploads/2018/03/Agility-EmergingMarkets-Logistics-Index-2018.pdf (Erişim:19.12.2018).

Arvis, J. F., Mustra, M. A., Ojala, L., Shepherd, B. ve Saslavsky, D. (2010). The logistics performance index and its indicators. Connecting to Compete 2010. The World Bank: USA.

Arvis, J. F., Mustra, M. A., Ojala, L., Shepherd, B. ve Saslavsky, D. (2012). The logistics performance index and its indicators. Connecting to Compete 2012. The World Bank: USA.

Arvis, J. F., Saslavsky, D., Ojala, L., Shepherd, B., Busch, C. ve Raj, A. (2014). The logistics performance index and its indicators. Connecting to Compete 2014. The World Bank: USA.

Arvis, J. F., Saslavsky, D., Ojala, L., Shepherd, B., Busch, C., Raj, A. ve Naula, T. (2016). The logistics performance index and its indicators. Connecting to Compete 2016. The World Bank: USA.

Arvis, J. F., Ojala, L., Wiederer C., Shepherd, B., Raj, A., Dairabayeva, K. ve Kiiski, T. (2018). The Logistics performance index and its indicators. Connecting to Compete 2018. The World Bank: USA.

Aghdaie, M. H., Zolfani, S. H. ve Zavadskas, E. K. (2013). Decision making in machine tool selection: An integrated approach with SWARA and COPRAS-G methods. Engineering Economics, 24(1): 5-17.

Albayrak, Ö. ve Erkayman, B. (2018). Bulanık Dematel ve EDAS yöntemleri kullanılarak sporcular için akıllı bileklik seçimi. Ergonomi, 1(2), 92-102. 
Ayaydın, H., Durmuş, S. ve Pala, F. (2017). Gri İlişkisel Analiz Yöntemiyle Türk lojistik firmalarında performans ölçümü. Gümümşhane Üniversitesi Sosyal Bilimler Enstitüsü Dergisi, 8(21), 76-94.

Ayyıldız, E. ve Demirci, E. (2018). Türkiye'de yer alan şehirlerin yaşam kalitelerinin SWARA entegreli TOPSIS yöntemi ile belirlenmesi. Pamukkale Üniversitesi Sosyal Bilimler Enstitüsü Dergisi, (30), 67-87.

Bayraktutan, Y., Tüylüoğlu, Ş. ve Özbilgin, M. (2012). Lojistik sektöründe yoğunlaşma analizi ve lojistik gelişmişlik endeksi: Kocaeli örneği. Uluslararası Alanya İsletme Fakültesi Dergisi, 4(3), 61-71.

Başar, S. İ. ve Bozma, G. (2017). Ülkelerin lojistik performanslarının belirleyicileri, Kafkas Üniversitesi Sosyal Bilimler Enstitüsü Dergisi, 20, 447-458.

Civelek, M. E., Uca, N. ve Çemberci, M. (2015). The mediator effect of logistics performance index on the relation between competitiveness index and gross domestic product. European Scientific Journal, 11(13), 368-375.

Çakır, E. (2017). Kentsel dönüşüm kapsamında müteahhit firmanın SWARA-Gri İlişkisel Analiz yöntemiyle seçilmesi. The Journal of International Scientific Researches, 2(6), 79-95.

Çakır, E. (2018). Elektronik Belge Yönetim Sistemi (EBYS) yazılımı seçiminde çok kriterli karar verme yöntemleri: Bir belediye örneği. Business, Economics and Management Research Journal, 1(1), 15-30.

Çakır, E. ve Karabıyık, B. K. (2017). Bütünleşik SWARA-COPRAS yöntemi kullanarak bulut depolama hizmet sağlayıcılarının değerlendirilmesi. Bilişim Teknolojileri Dergisi, 10(4), 417-434.

Çakır, E., Akel, G. ve Doğaner, M. (2018). Türkiye'de faaliyet gösteren özel alışveriş sitelerinin bütünleşik SWARA-WASPAS yöntemi ile değerlendirilmesi. Uluslararası İktisadi ve İdari İncelemeler Dergisi, 599616.

Çakır, S. ve Perçin, S. (2013). Çok Kriterli karar verme teknikleriyle lojistik firmalarında performans ölçümü. Ege Akademik Baklş, 13(4), 449-459.

$\begin{array}{lllll}\text { Deniz Ticaret } & \text { Odas1 } & \text { (2017). }\end{array}$ http://www.denizticaretodasi.org.tr/Shared\%20Documents/Deniz\%20Ticar eti\%20Dergisi/kasim_ek_2017.pdf (Erişim: 19.12.2018). 
Gergin, R. E. ve Baki, B. (2015). Türkiye'deki bölgelerin lojistik performanslarının bütünleştirilmiş AHS ve TOPSIS yöntemiyle değerlendirilmesi. Business and Economics Research Journal, 6(4), 115135 .

Ghorabaee, M. K., Zavadskas, E. K., Amiri, M. ve Turskis, Z. (2016). Extended EDAS method for fuzzy multi-criteria decision-making: an application to supplier selection. International Journal of Computers Communications \& Control, 11(3), 358-371.

Güner, S. ve Coşkun, E. (2012). Comparison of impacts of economic and social factors on countries' logistics performance: A Study with OECD Countries. Research in Logistics \& Production, 2(4), 329-343.

Işık, A. T. ve Adalı, E. A. (2016). A new integrated decision making approach based on SWARA and OCRA methods for the hotel selection problem. International Journal of Advanced Operations Management, 8(2), 140151.

Kalkınma Bakanlığı (2013). 10. Kalkınma Planı 2014-2018. https://pbk.tbmm.gov.tr/dokumanlar/10-kalkinma_plani.pdf (Erişim: 19.12.2018).

Karabasevic, D., Stanujkic, D., Urosevic, S. ve Maksimovic, M. (2015). Selection of candidates in the mining industry based on the application of the SWARA and the MULTIMOORA methods. Acta Montanistica Slovaca, 20(2).

Karabıyık, B. K. ve Gündoğmuş, M. E. (2018). Üniversitelerde bilgi sistemi seçim kriterlerinin swara yöntemi ile ağırlıklandırılması: Ampirik bir çalışma. Işsletme Bilimi Dergisi, 6(1), 59-85.

Keršulienè, V. ve Turskis, Z. (2011). Integrated fuzzy multiple criteria decision making model for architect selection. Technological and Economic Development of Economy, 17(4), 645-666.

Keršuliene, V., Zavadskas, E. K. ve Turskis, Z. (2010). Selection of rational dispute resolution method by applying new step- wise weight assessment ratio analysis (SWARA). Journal of Business Economics and Management, 11(2), 243-258.

Keshavarz Ghorabaee, M., Zavadskas, E. K., Olfat, L. ve Turskis, Z. (2015). Multi-criteria inventory classification using a new method of evaluation based on distance from average solution (EDAS). Informatica, 26(3), 435451. 
Korinek, J. ve Sourdin, P. (2011). To what extent are high- quality logistics services trade facilitating?. OECD Trade Policy Papers, No. 108, Paris.

Kunadhamraks, P., ve Hanaoka, S. (2008), Evaluating the logitics performance of intermodal transportation in Thailand. Asia Pacific Journal of Marketing and Logistics, 20(3), 323- 342.

Marti, L., Puertas, R., ve García, L. (2014). The importance of logistics Performance indeks in International Trade. Applied Economics, 46(24), 2982-2992.

MÜSİAD (2015). Lojistik sektöründe sürdürülebilirlik: yeşil lojistik. 2015 Lojistik Sektörü Raporu, MÜSİAD Araştırma Raporları, İstanbul.

Ojala, L, ve Çelebi, D. (2015). The World Bank's Logistics Performance Index (LPI) and drivers of logistics performance. International Transport Forum, OECD Papers, Queretaro.

Özbek, A. (2018). BİST'te işlem gören faktoring şirketlerinin mali yapılarının çok ölçütlü karar verme yöntemleri ile değerlendirilmesi. Yönetim ve Ekonomi, 25(1), 29-53.

Özbek, A. ve Demirkol, İ. Lojistik sektöründe faaliyet gösteren işletmelerin SWARA ve GİA yöntemleri ile analizi. Kırıkkale Üniversitesi Sosyal Bilimler Dergisi, 8(1), 71-86.

Özbek, A. ve Engür, M. (2018). EDAS yöntemi ile lojistik firma web sitelerinin değerlendirilmesi. Selçuk Üniversitesi Sosyal Bilimler Meslek Yüksekokulu Dergisi, 21(2), 417-429.

Ruzgys, A., Volvačiovas, R., Ignatavičius, Č. ve Turskis, Z. (2014). Integrated evaluation of external wall insulation in residential buildings using SWARA-TODIM MCDM method. Journal of Civil Engineering and Management, 20(1), 103-110.

Shang, K. C. ve Marlow, P. B. (2005). Logistics capability and performance in Taiwan's major manufacturing firms. Transportation Research Part E, 41, 217-234.

Shukla, S., Mishra, P. K., Jain, R. ve Yadav, H. C. (2016). An integrated decision making approach for ERP system selection using SWARA and PROMETHEE method. International Journal of Intelligent Enterprise, 3(2), 120-147. 
Stanujkic, D., Karabasevic, D. ve Zavadskas, E. K. (2015). A framework for the selection of a packaging design based on the SWARA method. Inzinerine Ekonomika-Engineering Economics, 26(2), 181-187.

Toklu, M. C., Çağıl, G., Pazar, E. ve Faydalı, R. (2018). SWARA-WASPAS metodolojisine dayalı tedarikçi seçimi: türkiye'de demir-çelik endüstrisi örneği. Akademik Platform Mühendislik ve Fen Bilimleri Dergisi, 6(3), 113-120.

Ulutaş, A. (2017). EDAS Yöntemi kullanılarak bir tekstil atölyesi için dikiş makinesi seçimi. İşletme Araştırmaları Dergisi, 9(2), 169-183.

Yapraklı, T. Ş. ve Ünalan, M. (2016). Küresel lojistik performans endeksi ve türkiye'nin son 10 yıllık lojistik performansının analizi. Atatürk Üniversitesi Íktisadi ve İdari Bilimler Fakültesi Dergisi, 31(3), 589-606.

Yurdoğlu, H. ve Kundakcı, N. (2017). SWARA ve WASPAS yöntemleri ile sunucu seçimi. Balikesir University Journal of Social Sciences Institute, 20(38).

Zolfani, S. H., Salimi, J., Maknoon, R. ve Kildiene, S. (2015). Technology foresight about R\&D projects selection; application of SWARA method at the policy making level. Engineering Economics, 26(5), 571-580. 


\title{
Evaluation of the Logistics Performance of OECD Countries with EDAS Method Based on SWARA
}

\author{
Extended Abstract
}

\section{Introduction}

In recent years, the importance given to the logistics sector has increased due to both its impact on national economies and its contribution to competitiveness. Logistics is directly related to the economy in terms of covering the activities related to the efficient organization of all kinds of materials and information flow from the production point to the point of consumption. It is observed that commercial activities of countries with high logistics performance have also improved.

Logistics, as well as growth potential it carries in itself is very important role to play as reaching many economic targets. The worldwide volume of logistics services is increasing day by day. In Turkey, it is known that the share of the logistics industry is over $\$ 100$ billion within its $\$ 720$ billion Gross Domestic Product (GDP), and GDP of 14\% consist of logistics services. Since 2007, The World Bank has presented Logistics Performance Index (LPI) in its extensive research to measure the logistics performance of countries regularly, on this basis, in recent years, Turkey's logistics performance seems to make no progress. In the 2018 report, Turkey has 3.15 points in 47 . rank out of 160 countries.

Turkey has to fulfill its goals about improving logistics performance in line with its geographical location and economic growth targets that presented in the development plans. At this point, our country cooperates with other countries on issues such as development, economy and trade. Turkey also is a member of the OECD (Organization for Economic Cooperation and Development) is one of the countries with the highest GDP growth within the OECD countries. As of 2018, it has an annual growth rate of $5.1 \%$. There is no doubt that Turkey's position and extension of its position will depend on the performance of the logistics industry. In this context, it is aimed to evaluate the logistics performance of OECD countries in an integrated way by using Multi Criteria Decision Making (MCDM) methods with respect to the LPI measure. In addition, the study aims to contribute to the literature in terms of the methods used and logistics performance evaluation.

\section{Method}

In the study an integrated MCDM approach was used that consists EDAS method based on SWARA. MCDM techniques allow the solution of the problems that require the evaluation of a large number of criteria and alternatives. SWARA (Step-wise Weight Assessment Ratio Analysis) method was used to perform weighting process on the basis of criteria of 6 main indicators under LPI and expert opinions were used. In this method, experts determine the importance of each criterion by making use of their own knowledge and then list all criteria from the first criterion to the last one. In the decision-making process, the importance rankings were determined according to the evaluations of six different expert decision makers composed of the representatives of the logistics sector and academicians. After criteria weighting process, The EDAS (Evaluation based on Distance from Average Solution) method was used to rank the 36 OECD countries according to their logistics performance. In the process of determining the best of the decision alternatives, EDAS is the method of evaluation based on the average solution distance. For each country, assessment scores were calculated and performance rankings were obtained. 
LPI (by World Bank) indicators represent the criteria for evaluating the logistics performance of the OECD countries and these 6 main criteria are determined as 1) Customs and border management 2) Trade and transport infrastructure 3) International shipment 4) Logistics service quality 5) Track and trace 6) Delivery time. In addition, country data of logistics performance indicators are obtained from the reports issued by the World Bank (2018).

\section{Results and Discussion}

According to the results of the application, the most important logistics performance criteria are determined as logistics service quality, trade and transport infrastructure and international shipment. It is concluded that the countries with the highest logistics performance are Germany, the Netherlands and Sweden, respectively. The countries with the lowest logistics performance are Latvia, Mexico and Slovakia, respectively. As for Turkey, it is ranked at place 27 within 36 countries.

\section{Conclusion}

Measuring logistics performance has gained importance in terms of increasing trade volumes of countries, achieving growth and competitiveness. In this study, for the aim of evaluating the logistics performance of OECD countries, MCDM methods have been used by integration of SWARA and EDAS. From the results the countries with the highest logistics performance were Germany, the Netherlands and Sweden. When evaluated on the basis of the most important criteria, it is observed that the countries with high logistic performance scores are also obtained very high scores related these criteria, in other words, the logistics services of these countries are high in quality, their logistics infrastructure is developed and they are effective in regulating international shipments. According to the rank of Turkey as 27 and considering the growth targets of Turkey, this case is not satisfactory from the point of logistics industry. Especially having an important place in terms of GDP growth among OECD countries, Turkey should keep impact of logistics on the economy at the forefront. Turkey's lowest score of logistics performance indicator appeared to be associated with the effective management of customs procedures. Considering Turkey's geographical location advantages created Logistics Master Plans and roadmaps will also contribute to the rise of the logistics performance. In future studies, performance evaluations of the logistics sector can be made with different types of MCDM techniques or analysis methods. Considering more indicators or criteria, logistics performance of countries or regions can be measured and solutions can be offered within this scope. 